\title{
European survey of hepatitis B vaccination policies for healthcare workers: An updated overview
}

\author{
Antoon De Schryver ${ }^{\mathrm{a}, \mathrm{b}, *}$, Tom Lambaerts ${ }^{\mathrm{b}}$, Nathalie Lammertyn ${ }^{\mathrm{b}}$, Guido François ${ }^{\mathrm{a}}$, Simon Bulterys ${ }^{\mathrm{b}}$, \\ Lode Godderis ${ }^{\mathrm{b}, \mathrm{c}}$
}

a Department of Epidemiology and Social Medicine, University of Antwerp, Universiteitsplein 1, BE-2610 Antwerp, Belgium

${ }^{\mathrm{b}}$ IDEWE Occupational Services, Interleuvenlaan 58, BE 3001 Leuven, Belgium

${ }^{\mathrm{c}}$ Department of Public Health and Primary Care, KU Leuven, Kapucijnenvoer 35 blok d, bus 7001, BE 3000 Leuven, Belgium

\section{A R T I C L E I N F O}

\section{Article history:}

Received 9 October 2019

Received in revised form 30 January 2020

Accepted 2 February 2020

Available online $\mathrm{xxxx}$

\section{Keywords:}

Hepatitis B

Vaccination

Policy

Healthcare workers

Europe

EU

Survey

Occupational medicine

\begin{abstract}
A B S T R A C T
Background: The risk of transmission of bloodborne pathogens, including hepatitis B virus (HBV) to healthcare workers (HCWs) is well known. In 2005 we performed a survey on HBV prevention in HCWs in the European Union (EU). An update of the 2005 survey deemed necessary as an EU Council Directive (2010/32/EU) on sharps injuries was to be implemented into national legislation by 11 May 2013 and more countries were starting universal HBV vaccination.

Methods: We performed an electronic survey in 2016, among national representatives from the Occupational Medicine section of the European Union of Medical Specialists (UEMS), to find out how policies have been put into practice in the European Union countries (plus Norway and Switzerland). The data were updated in 2019.

Results: Answers were received from 21 countries (among them 19 EU Member States), representing 78\% of the population and $60 \%$ of HCWs in the EU-28. HBV vaccination was mandatory for medical and nursing staff in 10 countries; for other paramedical staff, medical and nursing students in 9 countries; for paramedical students in 8 countries; for cleaning staff in 7 countries; and for technical staff in 5 countries; it was recommended in all but one of other countries. Serotesting before vaccination was done in 7 countries. The vaccination schedule most often used was $0,1,6$ months (18countries), monovalent $\mathrm{HBV}$ vaccine was used in 14 countries, and combined (HAV + HBV) vaccine in 11 countries. Serotesting after vaccination was done in 18 countries and boosters were recommended in 14 countries. A nonresponder policy was present in 18 countries. HBV vaccination coverage (5 countries) was $70-95 \%$. Sharps injuries were reported in 13 countries, nationwide in 7 of them; European-wide reporting was not mentioned by respondents.

Discussion: These results show the variation in the implementation of EU legislation in the participating countries. More consultation between actors at EU level, including enhancing medical surveillance in occupational medicine could help to optimise policies in European countries in order to further reduce HBV transmission to HCWs.
\end{abstract}

() 2020 Published by Elsevier Ltd.

\section{Introduction}

The occupational risk of transmission of bloodborne pathogens, including hepatitis B virus (HBV) to healthcare workers (HCWs) is well recognised [1].The most common routes of transmission from patient to HCW are needlestick or sharps injuries, followed by mucocutaneous exposure. A range of measures and interventions

\footnotetext{
* Corresponding author at: Department of Epidemiology and Social Medicine University of Antwerp, Universiteitsplein 1, BE-2610 Antwerp, Belgium.

E-mail address: antoon.deschryver@uantwerpen.be (A. De Schryver)
}

can contribute to reduce HBV transmission to HCWs, such as the adoption of standard precaution measures and the use of safety devices. The introduction of HBV vaccines in the 1980s, however, is to be considered the major achievement in terms of prevention of HBV infection. HBV vaccination of HCWs and guaranteeing optimum immunisation coverage is therefore a wise strategy [1]. Postexposure prophylaxis (PEP) after needlestick or sharps injuries completes the picture.

Under current European Union (EU) legislation, all employers have to perform a risk assessment to identify workers exposed to $\mathrm{HBV}$, to inform them about the risk and how to prevent it, 
including vaccination [2]. Moreover, vaccination should be given as soon as possible after the start of the career of HCWs in order to avoid HBV infection and its long-term consequences, particularly development of a carrier status [3].

We have published an overview of the information on HBV vaccination policies for HCWs in the different EU Member States (MS) plus Norway and Switzerland in 2011 [4]. However, an update of this overview deemed necessary i.a. in view of the introduction of universal HBV vaccination programmes making a change of vaccination policies for HCWs necessary [5] and a new European Council Directive 2010/32EU on prevention of sharps injuries in the hospital and healthcare sector [6]. This directive focused specifically on the prevention of medical sharps injuries and the transmission of bloodborne pathogens (including HBV infection) in the healthcare sector, including specific reporting mechanisms at local, national and European-wide level. The EU MS were expected to implement this into national legislation by 11 May 2013.

\section{Methods}

The purpose of the current study was to provide an update, identifying analogies, differences, and gaps in policies in place between different EU MS plus Norway and Switzerland, and to report changes in legislation and practice since the previous study. Therefore, we performed a descriptive quantitative study using a structured on-line self-administered questionnaire to survey HBV vaccination policies in HCWs in EU MS $(n=28)$ plus Norway (NO) and Switzerland $(\mathrm{CH})$ in 2016. The latter two countries were included because, first, they had also been included in our previous study and second, they have a trading arrangement with the EU requiring them to follow EU rules (including changes) in their own laws. The survey was conducted from June through August 2016. The questionnaire was adapted from the one used in our previous study, making questions more specific on vaccination schedules, pre- and postvaccination testing, types of vaccines used, booster and non-responders policies, providing more answer categories, adding questions on universal vaccination programmes and their impact on vaccination policies for HCWs, and on new European legislation on sharps injuries [4]. In its final version it contained 8 parts with easy-to-answer open and closed questions: the definition of a HCW, general issues, universal vaccination policy, targeted vaccination policy and pre-vaccination testing, HBV post-vaccination testing, booster policy and reporting of sharps injuries.

As a working definition, a HCW was considered as a person who has professional contacts with patients and/or is potentially exposed to contamination sources inside and outside the hospital. According to this definition, a HCW belongs to one of the following professional categories: medical staff, nursing staff, other paramedical staff, medical students, student nurses, other paramedical students, technical staff, and cleaning staff.

As the issue of mandatory vaccination for HCWs has frequently been discussed in the literature [7-12], we compared countries having mandatory policies with countries without such a policy in terms of epidemiology of HBV, geographical position in Europe, GDP per capita, and year of introduction of universal HBV vaccination [13-14]. For this we compared 10 countries having lowest HBV prevalence, highest GDP per capita and situated most northwest, to 11 countries with highest HBV prevalence, lowest GDP per capita and situated most southeast.

A non-responder to HBV vaccination was defined as a person whose serum anti-HBs concentration is lower than $10 \mathrm{IU} / \mathrm{l}$, as measured one month after completion of a primary complete vaccination course.
Participants were questioned about non-responders policies in an open question.

The questionnaire was first circulated among vaccination specialists, who were identified through their extensive publication record, and members of the Viral Hepatitis Prevention Board (VHPB) for comments. The concept and the practical modalities of the survey were discussed and agreed upon at a meeting of the national representatives in the Occupational Medicine Specialist section of the 'Union Européenne des Médecins Spécialistes' (European Union of Medical Specialists/UEMS) [15].

The questionnaires were sent through e-mail to the UEMS national representatives in 26 EU Member States (no contact persons were identified in Cyprus and Slovakia) plus Norway and Switzerland. They were asked to send us the contact details of at least one authorative colleague in regard to occupational HBV vaccination of HCWs in their country. If no answer was received within three weeks after the first mailing, a reminder was sent, equally by e-mail.

In december 2019, participants were asked to re-verify the submitted results of the survey.

\section{Results}

Answers were received from 21 countries: 19 EU MS (Austria/ AT, Belgium/BE, Croatia/HR, Czech Republic/CZ, Estonia/EE, France/FR, Germany/DE, Greece/GR, Hungary/HU, Ireland/IE, Italy/ IT (incomplete answers), Latvia/LV, Luxembourg/LU, the Netherlands/NL, Poland/PL, Portugal/PT, Slovenia/SI, Spain/ES and Sweden/SE) plus Norway/NO and Switzerland/CH. The participating 19 EU MS represented $77.4 \%$ of the total EU population and $60 \%$ of the total number of HCWs in the EU at the time of the survey [16-17]. In the 2019 update of the results we received answers from 11 countries and the data were adapted where necessary.

The proposed definition of a HCW was agreed upon with one exception: medical students are not considered as HCWs in Latvia.

\subsection{General issues}

The first aspect to explore was whether the occupational health laws and regulations in a specific country were valid for the whole country. This turned out to be the case in all participating countries.

\subsection{Universal vaccination}

Universal HBV vaccination programmes were present at the time of the survey in all countries except in Sweden and Norway (SE and NO) introduced their programme in 2017). They were all introduced between 1991 (IT) and 2017 (NO).

\subsection{Vaccination policies}

National HBV vaccination policies for employees and students are shown in Table 1 and Fig. 1. Vaccination against HBV infection is mandatory for medical and nursing staff in 10 countries $(\mathrm{BE}, \mathrm{CZ}$, FR, HU, LV, HR, NL, PL, PT, SI); and also mandatory for (other) paramedical staff in 9 of these 10 countries (not in CZ). It is recommended for medical, nursing, and other paramedical staff in all other countries. There were no penalties for refusing vaccination nor incentives for all HCW categories to be vaccinated.

For cleaning staff, HBV vaccination is mandatory in 7 countries (BE, FR, HU, HZ, LV, PT, SI), for technical staff in 5 countries (BE, EE, FR, HU, PT). It is recommended for both groups in all other countries except in Sweden. 
Table 1

Hepatitis B vaccination policies for different categories of healthcare workers (including students) in European countries.

\begin{tabular}{|c|c|c|c|c|c|c|c|c|}
\hline Country & Medical staff & Nursing staff & Paramedical staff & Technical staff & Cleaning staff & Medical students & Student nurses & Paramedical students \\
\hline Austria (AT) & $\mathrm{R}$ & $\mathrm{R}$ & $\mathrm{R}$ & $\mathrm{R}$ & $\mathrm{R}$ & $\mathrm{R}$ & $\mathrm{R}$ & $\mathrm{R}$ \\
\hline Belgium (BE) & M & M & M & M & M & M & M & M \\
\hline Croatia (HR) & M & M & M & $\mathrm{R}$ & M & M & M & M \\
\hline Czech Republic (CZ) & M & M & $\mathrm{R}$ & $\mathrm{R}$ & $\mathrm{R}$ & M & M & M \\
\hline Estonia (EE) & $\mathrm{R}$ & $\mathrm{R}$ & $\mathrm{R}$ & M & $\mathrm{R}$ & $\mathrm{R}$ & $\mathrm{R}$ & $\mathrm{R}$ \\
\hline France (FR) & M & M & M & M & M & M & M & M \\
\hline Germany (DE) & $\mathrm{R}$ & $\mathrm{R}$ & $\mathrm{R}$ & $\mathrm{R}$ & $\mathrm{R}$ & $\mathrm{R}$ & $\mathrm{R}$ & $\mathrm{R}$ \\
\hline Greece (GR) & $\mathrm{R}$ & $\mathrm{R}$ & $\mathrm{R}$ & $\mathrm{R}$ & $\mathrm{R}$ & $\mathrm{R}$ & $\mathrm{R}$ & $\mathrm{R}$ \\
\hline Hungary (HU) & M & M & M & M & M & M & M & M \\
\hline Ireland (IE) & $\mathrm{R}$ & $\mathrm{R}$ & $\mathrm{R}$ & $\mathrm{R}$ & $\mathrm{R}$ & $\mathrm{R}$ & $\mathrm{R}$ & $\mathrm{R}$ \\
\hline Italy (IT) & $\mathrm{R}$ & $\mathrm{R}$ & $\mathrm{R}$ & $\mathrm{R}$ & $\mathrm{R}$ & $\mathrm{R}$ & $\mathrm{R}$ & $\mathrm{R}$ \\
\hline Latvia (LV) & M & M & M & $\mathrm{R}$ & M & $\mathrm{R}$ & $\mathrm{R}$ & $\mathrm{R}$ \\
\hline Luxembourg (LU) & $\mathrm{R}$ & $\mathrm{R}$ & $\mathrm{R}$ & $\mathrm{R}$ & $\mathrm{R}$ & $\mathrm{R}$ & $\mathrm{R}$ & $\mathrm{R}$ \\
\hline Netherlands (NL) & M & M & M & $\mathrm{R}$ & $\mathrm{R}$ & M & M & $\mathrm{R}$ \\
\hline Norway (NO) & $\mathrm{R}$ & $\mathrm{R}$ & $\mathrm{R}$ & $\mathrm{R}$ & $\mathrm{R}$ & $\mathrm{R}$ & $\mathrm{R}$ & $\mathrm{R}$ \\
\hline Poland (PL) & M & M & M & $\mathrm{R}$ & $\mathrm{R}$ & M & M & M \\
\hline Portugal (PT) & M & M & M & M & M & M & M & M \\
\hline Slovenia (SI) & $\mathrm{M}$ & M & M & $\mathrm{R}$ & M & M & M & M \\
\hline Spain (ES) & $\mathrm{R}$ & $\mathrm{R}$ & $\mathrm{R}$ & $\mathrm{R}$ & $\mathrm{R}$ & $\mathrm{R}$ & $\mathrm{R}$ & $\mathrm{R}$ \\
\hline Sweden (SE) & $\mathrm{R}$ & $\mathrm{R}$ & $\mathrm{R}$ & $\mathrm{N}$ & $\mathrm{N}$ & $\mathrm{R}$ & $\mathrm{R}$ & $\mathrm{R}$ \\
\hline Switzerland $(\mathrm{CH})$ & $\mathrm{R}$ & $\mathrm{R}$ & $\mathrm{R}$ & $\mathrm{R}$ & $\mathrm{R}$ & $\mathrm{R}$ & $\mathrm{R}$ & $\mathrm{R}$ \\
\hline
\end{tabular}

M: mandatory; R: recommended; N: neither mandatory nor recommended.

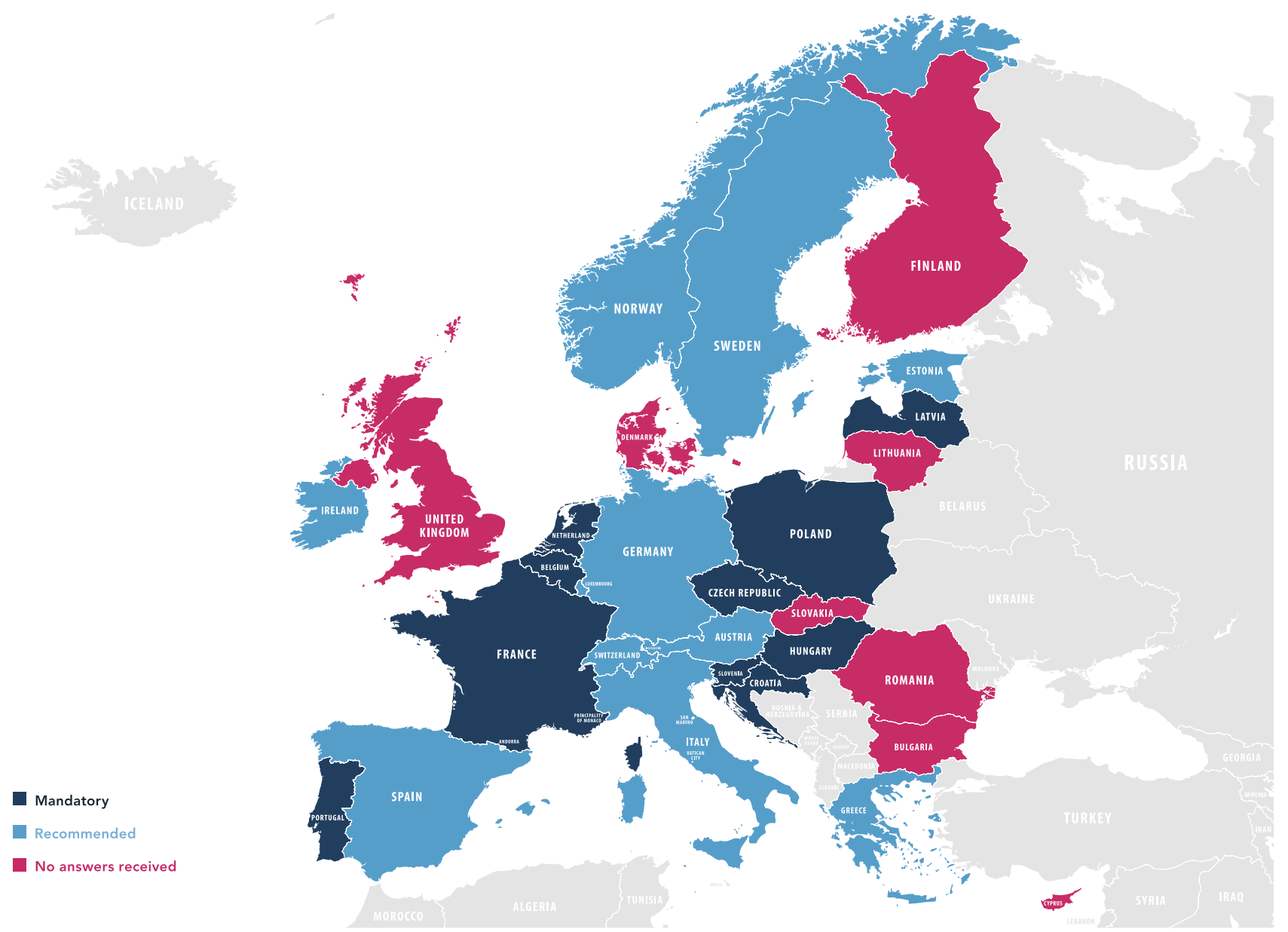

Fig 1. Map indicating the countries where hepatitis B vaccination is mandatory or recommended for most groups of health workers.

The different HBV vaccination policies for students are also summarised in Table 1 . Vaccination is mandatory for medical students and student nurses in 9 countries (BE, CZ, FR, HU, HR, LV, NL, PL, PT, SI); and for other paramedical students in 8 countries (BE,
CZ, FR, HU, HR, PL, PT, SI). It is recommended for these categories in all other participating countries.

Countries from the eastern and southern part of the EU have shown to have a higher prevalence of HBV infection than northern 
and western parts [13]; in our study eastern and southern countries had more mandatory policies ( $7 / 11$ countries) compared to northern and western countries (3/10). Countries with a lower GDP also had more mandatory policies than richer countries: of the 11 poorest $7 / 11$ had mandatory policies while in the 10 richest only 3 had mandatory policies. The introduction year of universal vaccination programmes showed no link with mandatory or not; of 11 countries that introduced universal vaccination before 1999, 4/11 had mandatory policies; of 10 countries having done this from 1999 onwards 5/10 had mandatory policies.

\subsection{Pre-vaccination testing}

Serotesting before HBV vaccination is done in 7 countries (BE, CZ, EE, GR, LU, SI, SE) for nursing staff, student nurses, and paramedical students. In 6 it is done for medical staff, medical students, and other paramedical staff (not in LU). In 5 countries it is done for technical staff (BE, EE, GR, LU, SI) and in 4 countries for cleaning staff (BE, EE, GR, SI).

Among the countries performing HCW testing before HBV vaccination, anti-HBs is tested in 5 of them (BE, CZ, LU, SI, SE), anti-HBc in 3 of them (EE, GR, SI), HBsAg in four (BE, EE, LU, SI). In several countries (BE, EE, $\mathrm{LU}, \mathrm{SI}$ ), several tests are used together. No country reported to use HBV DNA as a pre-vaccination test.

\subsection{Vaccination timing and schedule}

HBV vaccination is reported to be done at the start of the involved HCW's career in 20 of the participating countries; only in Sweden this is not explicitly stated (results not shown). Medical students and student nurses are vaccinated in 20 countries, though in Sweden there is no standard moment when it will be given. Paramedical students are not routinely vaccinated in the Czech Republic, although vaccination for this group is reported to be mandatory in $\mathrm{CZ}$ (Table 1 ). The vaccination schedule most often applied (in 18 out of 21 countries) is $0,1,6$ months. The schedule $0,1,2,12$ months is used in 7 countries, often (in 3 countries) as an accelerated course (GR, HU, ES). In 6 countries (HR, GR, HU, IE, PT, ES), different schedules (0, 1, 6 and $0,1,2,12$ months) coexist.

\subsection{Type of HBV vaccine, post-vaccination testing, and booster policy}

A combined (HAV + HBV) vaccine is used in 11 of the participating countries (19 anwers received). A monovalent HBV vaccine is used in 14 countries, while in some countries both types of vaccine are used. Three countries (FR, GR, ES) use an adjuvanted vaccine, alone or in combination, and both Croatia and Hungary use a recombinant DNA absorbed vaccine (Table 2).

Serological testing (anti-HBs) after HBV vaccination is reported to be performed in 18 countries ( 20 answers received); not in LV and PL. All staff (including students) are tested in 13 countries. Serotesting is done for selected categories of staff and/or students in 4 countries, in one country (EE) the categories were not specified (Table 2).

The time span between administration of the last vaccine dose and serological testing is between 4 and 8 weeks: 4 weeks in 11 countries, 4-6 weeks in 2 countries, and 6-8 weeks in 5 countries (data not shown).

The anti-HBs level considered protective in serological postvaccination testing is $10 \mathrm{IU} / \mathrm{l}$ in 12 out of 18 countries. Six countries (AT, DE, IE, LU, NO, CH) preferred a threshold level of $100 \mathrm{IU} / \mathrm{l}$.

Administration of a HBV vaccine booster dose (defined as any revaccination after a completed vaccination schedule) is recommended in 14 countries (20 answers received; see Table 3), compared to 10 in our previous study. In 11 countries only the results of serological screening determined the administration of
Table 2

Type of HBV vaccine used, post-vaccination testing, and booster policy for HBV vaccination for different categories of healthcare workers (including students) in European countries.

\begin{tabular}{|c|c|c|c|}
\hline Country & $\begin{array}{l}\text { Type of } \\
\text { HBV } \\
\text { vaccine }\end{array}$ & $\begin{array}{l}\text { Post- } \\
\text { vaccination } \\
\text { testing }(\mathrm{Y} / \mathrm{N})\end{array}$ & Type of staff \\
\hline Austria (AT) & $\mathrm{C}$ & $\mathrm{Y}$ & all staff \\
\hline Belgium (BE) & $M+C$ & $\mathrm{Y}$ & all staff \\
\hline Croatia (HR) & $\mathrm{R}$ & $\mathrm{Y}$ & $\begin{array}{l}\text { all staff, except } \\
\text { technical/cleaning }\end{array}$ \\
\hline $\begin{array}{l}\text { Czech Republic } \\
\quad \text { (CZ) }\end{array}$ & $M+C$ & $\mathrm{Y}$ & $\begin{array}{l}\text { all staff, except } \\
\text { paramedical/ } \\
\text { technical/cleaning }\end{array}$ \\
\hline Estonia (EE) & $M+C$ & $\mathrm{Y}$ & - \\
\hline France (FR) & A & $\mathrm{Y}$ & all staff \\
\hline Germany (DE) & $M+C$ & $\mathrm{Y}$ & all staff \\
\hline Greece (GR) & $A+C$ & $\mathrm{Y}$ & all staff \\
\hline Hungary (HU) & $R(M+C)$ & $\mathrm{Y}$ & all staff, except students \\
\hline Ireland (IE) & M & $\mathrm{Y}$ & all staff \\
\hline Italy (IT) & & - & \\
\hline Latvia (LV) & M & $\mathrm{N}$ & all staff \\
\hline Luxembourg (LU) & $\mathrm{C}$ & $\mathrm{Y}$ & $\begin{array}{l}\text { all staff, except cleaning } \\
\text { staff/medical students }\end{array}$ \\
\hline Netherlands (NL) & $M+C$ & $\mathrm{Y}$ & all staff \\
\hline Norway (NO) & $\mathrm{M}$ & $\mathrm{Y}$ & all staff \\
\hline Poland (PL) & M & $\mathrm{N}$ & - \\
\hline Portugal (PT) & M & Y & all staff \\
\hline Slovenia (SI) & M & $\mathrm{Y}$ & all staff \\
\hline Spain (ES) & $A+M+C$ & $\mathrm{Y}$ & all staff \\
\hline Sweden (SE) & - & Y & - \\
\hline Switzerland $(\mathrm{CH})$ & $M+C$ & $\mathrm{Y}$ & all staff \\
\hline
\end{tabular}

A: adjuvanted HBV vaccine; C: combined (HAV + HBV) vaccine; M: monovalent HBV vaccine; R: recombinant DNA HBV vaccine.

All staff: medical, nursing, paramedical, technical, and cleaning staff, and medical students, student nurses, and paramedical students.

a booster, one country (GR) used a time interval only, and in 2 countries (AT, IE) both factors (results of serological screening and time interval) were considered.

\subsection{Policy on non-responders}

We could identify 5 algorithms (see Table 3 ) for non-responders of which the most frequently used ( 8 countries) was: one booster followed by anti-HBs testing, if insufficient 2 doses at 1 and 6 months (see Table 3 for futher details). Switzerland used this algorithm too, but mentioned that, after the second series of vaccines, a non-responder was to be referred to a specialist. France uses the same algorithm as Norway (one booster dosis followed by antiHBs testing after 3 months, if insufficient complete schedule at 0,1 , 6 months), but tests for anti-HBs after each dose. The type of HBV vaccine used for non-responders also varied widely between countries, the monovalent vaccine was most frequently used (11countries), but some countries used a mix of different vaccine types (see Table 3). Non-responders were tested for carrier status in 12 countries, using different tests (see Table 3 ).

\subsection{Vaccination coverage}

Data on national HBV vaccination coverage among HCWs were published for 5 participating countries. Estimated coverage ranged from 70 to $100 \%$ (data not shown) [18-22].

\subsection{Reporting of sharps injuries}

Questions on reporting mechanisms, as prescribed in the EU Directive, were answered by 19 respondents. Reporting was avail- 
Table 3

Booster and non-responders policy for HBV vaccination for different categories of healthcare workers (including students) in European countries.

\begin{tabular}{|c|c|c|c|c|}
\hline Country & $\begin{array}{l}\text { When booster } \\
\text { recommended? }\end{array}$ & Test(s) used in non-responders to detect carrier status & $\begin{array}{l}\text { Non-responders policy } \\
\text { algoritm }\end{array}$ & Type of HBV vaccine \\
\hline Austria (AT) & Serology/time interval & - & (1) & $\mathrm{C}$ \\
\hline Belgium (BE) & Serology & anti-HBc & (4) & M \\
\hline Croatia (HR) & Serology & - & (2) & $\mathrm{R}$ \\
\hline Czech Republic (CZ) & Serology & - & (1) & $A+M+C$ \\
\hline Estonia (EE) & No booster recommended & - & (2) & - \\
\hline France (FR) & Serology & anti-HBc/HBV DNA & $(3)^{*}$ & A \\
\hline Germany (DE) & Serology & HBsAg/anti-HBc/HBV DNA & (1) & $M+C$ \\
\hline Greece (GR) & Time interval & HBsAg/anti-HBc/HBV DNA & (2) & A \\
\hline Hungary (HU) & No booster recommended & HBsAg/HBV DNA & (2) & $\mathrm{M}$ \\
\hline Ireland (IE) & Serology/time interval & HBsAg/anti-HBc & (1) & All \\
\hline Italy (IT) & - & - & - & - \\
\hline Latvia (LV) & No booster recommended & - & - & - \\
\hline Luxembourg (LU) & Serology & HBsAg/anti-HBc & (5) & M \\
\hline Netherlands (NL) & Serology & HBsAg/anti-HBc & (2) & $M+C+T$ \\
\hline Norway (NO) & Serology & HBsAg/anti-HBc & (3) & M \\
\hline Poland (PL) & No booster recommended & - & - & - \\
\hline Portugal (PT) & Serology & HBsAg/anti-HBc & (1) & M \\
\hline Slovenia (SI) & Serology & HBsAg/anti-HBc & (1) & M \\
\hline Spain (ES) & Serology & - & (1) & M \\
\hline Sweden (SE) & No booster recommended & - & (5) & - \\
\hline Switzerland $(\mathrm{CH})$ & No booster recommended & HBsAg/anti-HBc & $(1)^{*}$ & - \\
\hline
\end{tabular}

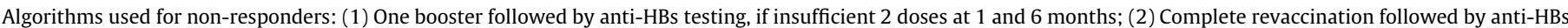

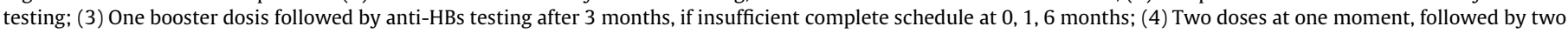
doses after 2 months; (5) One booster only. *Special algorithm for $\mathrm{CH}$ and France (see text).

A: adjuvanted HBV vaccine; C: combined (HAV + HBV) vaccine; M: monovalent HBV vaccine; R: recombinant DNA HBV vaccine; T: Third generation HBV vaccine.

able in 13 countries ( 4 respondents answered no and 2 did no tknow). Institutional (i.e., in hospitals, health centers, ...) reporting was available in 10 countries, local reporting (city, province, ...) in one country, and national reporting in 7. Aggregated data were publicly available in 6 countries. European-wide reporting was not mentioned.

\subsection{Comparison with previous study}

The most striking findings of the present study, compared to our previous study, are:

1. The vaccination policies ('mandatory', 'recommended' or 'neither mandatory nor recommended') in different countries and for different professional subgroups have remained largely unchanged.

2. Prevaccination testing is now done in 7 (instead of 6) countries.

3. Serotesting after vaccination has increased from 14 to 18 countries, but interpretation of the results differs between countries.

4. The presence of booster policies has increased from 10 to 14 countries.

\section{Discussion}

This survey is an update, 10 years after our previous study presenting an overview of different aspects of HBV vaccination policies in HCWs in different European countries [4].

Some of the answers we received on mandatory or recommended vaccination were somewhat different from other studies on HCW policies, although these differences were very minor [12,7-9].

There are several reasons for these differences.

First, the terms 'mandatory' and 'recommended' are actually close to one another. In our study, respondents reported that there were no penalties for refusing mandatory vaccination, which brings it very close to recommended vaccination.

Second, in the other studies mentioned, public health organisations and/or vaccine experts were used as respondents. We used experts in occupational medicine, therefore assuming that they had a good knowledge of both the legislative and practical aspects of HBV vaccination of HCWs in their respective countries.

Third, in other studies a slightly different definition of HCWs was used. This could explain some discrepancies in the answers between the studies.

Mandatory vaccination policies were more frequent in both eastern and southern countries; they have a higher prevalence of HBV infection and are also the poorer countries. There was no link with earlier introduction of universal HBV vaccination.

Although mandatory HBV vaccination of HCWs is advisable [911], comparison of published HBV vaccination coverage figures in HCWs does not show much difference between countries where vaccination is mandatory (e.g., Poland) and those where it is recommended, e.g., Switzerland [19,22]. Further studies would be needed to determine exactly if (and to what extent) a variation in terms of 'mandatory'or 'recommended' implies different coverage rates for different groups of HCWs in European countries. This was however beyond the scope of the present study.

Pre-vaccination serological testing for HCWs is still not widely done ( 7 countries). With the introduction of universal vaccination without systematic post-vaccination testing, large cohorts of HBV vaccinated youngsters are currently entering the healthcare profession, needing protection against HBV $[5,23]$. To determine those (student) HCWs not immune against HBV, a prevaccination strategy must be developed for them; further research on this topic is needed [24].

Most (19/21) countries used at least the classical 0, 1, 6 months or $0,1,2,12$ months schedules.

The number of countries using the combined vaccine slightly increased from 10 in our previous study to 11 in the present study. A new development is the use of newer generation vaccines (recombinant DNA HBV vaccine, adjuvanted vaccine) in some countries.

The practice of serotesting after HBV vaccination in HCWs is applied in 18 countries compared to 14 in our previous study, mostly for medical, nursing, and paramedical staff.

The maximum time elapsed between giving a final dose and performing the tests was never shorter than 4 weeks and never exceeded 8 weeks, as recommended, compared to a maximum of 3 months in our previous study $[3,25,26]$. 
Recommendations on protective serum anti-HBs concentrations differ somewhat in different groups of HCWs: $10 \mathrm{IU} / 1$ is most often cited as a threshold, but $100 \mathrm{IU} / \mathrm{l}$ has also been proposed, particularly in HCWs performing exposure prone procedures $[3,25,26]$.

In our study most countries (12 out of 18) had adopted $10 \mathrm{IU} / \mathrm{l}$ as a threshold, compared to 13 in our previous study, while 6 preferred $100 \mathrm{IU} / 1$. Working with a $100 \mathrm{IU} / 1$ threshold has the advantage of being usually above the levels measured in HBV carriers with concurrent serum HBsAg and anti-HBs [3,25] and a metaanalysis concluded that available data did not allow to exclude an increased risk for infection with time since vaccination [27]. But recent research has confirmed previous studies that a level of $\geq 10 \mathrm{IU} / \mathrm{l}$ confers a long-term (10-28 years) immunity in immunocompetent individuals that have adequately responded to a primary HBV vaccination course, even in the absence of HBV exposure [28,29].

Therefore, current recommendations state that no boosters are necessary in immunocompetent individuals that have adequately responded to a primary HBV vaccination course [25].

One of the more difficult issues is the policy on non-responders. We could identify five algorithms used by the participating countries. The two most frequently used algorithms, used by 13 $(8+5)$ countries are supported by the European Consensus Group recommendation and CDC.

Comparison of booster and non-responders policies with the policies described in our previous study was difficult, because the answers in that survey were rather confusing [4].

Another point of interest is the use of different vaccines for nonresponders. Five countries used at least a combined vaccine; interestingly, none mentioned the use of double doses of the combined (HAV + HBV) vaccine [30]. Interesting developments comprise the use of new vaccines, such as adjuvanted vaccines in 4 countries (CZ, FR, GR, IE) and the search for newer vaccines specifically developed for non-responders, some of which seem to offer perspectives [31].

Non-responders were tested for carrier status in 12 countries, as recommmended by the European Consensus Group and by CDC, using different tests. Ten countries used at least HBsAg as recommended by the European Consensus Group and CDC $[3,26]$.

Besides the 5 countries for which respondents report HBV coverage studies, there have been few other recent studies (IT, PL, HR) [32-34]. Coverages are comparable to those reported in our previous study and most countries did not reach $90 \%$ coverage proposed by WHO [35].

Published HBV vaccination coverage figures in HCWs in Europe are somewhat higher than those presented in North American studies; a recent report showed United States HBV vaccination coverage in HCWs to amount to 63\% [36]. This difference could be explained by the differences between US and EU occupational medicine systems and enhanced medical surveillance in the EU.

In the EU Directive on sharps injuries, there was a clause (clause 9) on reporting to include local, national and European-wide reporting systems, which could be instrumental in developing a harmonized approach in all EU countries.

From our survey, we conclude that in most countries reporting is available, both locally and nationally, but that there is no European-wide reporting. This is clearly a point that needs to be looked at in the future.

One of the strengths of our study is the participation of experts in occupational medicine, having a good practical knowledge of both legislative and practical aspects of HBV prevention. We conducted our survey using the same methodology as the previous one, which allowed us to study trends in HBV prevention in HCWs in Europe over the past decade. As a potential weakness, information on national policies was obtained from one person per country, while the implementation of the policy might differ among different actors in the country. This point could only be solved through organising a series of country-wide surveys, which was beyond the scope of our study.

Our survey, wherein a large majority of European HCWs is represented, reveals considerable variation among countries in the way EU legislation regarding HBV vaccination is translated into policy, particularly concerning the practical implication details. Compared to our previous study, it seems that the way different countries deal with this matter has not been optimised drastically. The European Directive 2010/32/EU, to be implemented by 11 May 2013, has not lead to the emergence of a European-wide reporting system of sharps injuries. Also, research is urgently needed on the vaccination strategies (including serotesting) proposed for (student) HCWs already vaccinated as a child and/or adolescent. This seems particularly important because of WHO's goal to eliminate viral hepatitis by 2030 [37]. The 'Global health sector strategy on viral hepatitis' adopted by the World Health Assembly, implies a massive testing strategy for viral hepatitis, with subsequent risks for infections in HCWs performing these duties. Recent surveillance data suggest that the number of cases of HBV infection in EU countries is already increasing, at least partly due to this strategy and this makes HBV vaccination in HCWs even more important [37]. More in-depth consultation between key actors from different countries (EU MS and other) and better coordination, including more harmonization and convergence of different occupational medicine systems (e.g., by enhancing medical surveillance), could contribute to optimise the way this crucial matter is dealt with in Europe and the elimination goal is reached [38]. This remains a future challenge for the Europan Union.

\section{Declaration of Competing Interest}

The authors declare that they have no known competing financial interests or personal relationships that could have appeared to influence the work reported in this paper.

\section{Acknowledgements}

The authors gratefully acknowledge the following occupational physicians for their participation: Alenka Skerjanc (chair), Alexiou Athanasios, Gabriella De Carli, Ugoa Dumpis, Tone Eriksen, Murillo Frazao, Maria Ganczak, Jean-François Gehanno, Ferenc Kudasz, Ann Lindstrand, Jaap Maas, Nicole Majéry, Christine Marty, Brigitte Merz, Peter Noone, P. Novosel, Mari Cruz Rodriguez Jareno, Riina Salupere, Oswin Rosenmayer, Miriam Schejbalova, Consol Serra, Wim Van Hooste, Sabine Wicker. They also thank Pierre Van Damme and Guido Van Hal for evaluating the first version of the questionnaire.

\section{CRediT authorship contribution statement}

Antoon De Schryver: Conceptualization, Methodology, Writing - original draft. Tom Lambaerts: Investigation, Validation, Formal analysis, Data curation. Nathalie Lammertyn: Supervision, Resources. Guido François: Conceptualization, Methodology, Writing - review \& editing. Simon Bulterys: Funding acquisition, Resources. Lode Godderis: Conceptualization, Methodology, Writing - review \& editing.

\section{Funding}

This work was carried out as a partial fulfillment of a Master thesis Occupational. 
Medicine; this research did not receive any specific grant from funding agencies in the public, commercial or non-for-profit sectors.

\section{Appendix A. Supplementary data}

Supplementary data to this article can be found online at https://doi.org/10.1016/j.bbi.2019.01.018.

\section{References}

[1] FitzSimons D, François G, De Carli G, Shouval D, Prüss-Üstün A, Puro V, et al. Hepatitis B virus, hepatitis C virus, and other blood-borne infections in healthcare workers: guidelines for prevention and management. Occup Environ Med 2008;65:446-51.

[2] European Union. Directive 2000/54/EC of the European Parliament and of the Council of 18 September 2000 on the protection of workers from risks related to exposure to biological agents at work (seventh individual directive within the meaning of Article 16(1) of Directive 89/391/EEC). Off J L 262,17/10/2000 P.0021-0045. ELI: http://data.europa.eu/eli/dir/2000/54/oj [accessed 23 January 2020].

[3] Gunson R, Shouval D, Roggendorf M, Zaaijer H, Nicholas H, Holzmann H, et al Consensus Group. Hepatitis B virus (HBV) and hepatitis C virus (HCV) infections in health care workers (HCWs): guidelines for prevention of transmission of HBV and HCV from HCW to patients. I Clin Virol 2003;27:213-30.

[4] De Schryver A, Claesen B, Meheus A, van Sprundel M, François G. European survey of hepatitis B vaccination policies for healthcare workers. Eur J Public Health 2011;21:338-43. https://doi.org/10.1093/eurpub/ckq122. Epub 2010 Sep 3.

[5] Lernout T, Hendrickx G, Vorsters A, Mosina L, Emiroğlu N, Van Damme P. A cohesive European policy for hepatitis B vaccination: are we there yet?. Clin Microbiol Infect 2014;20(suppl 5):19-24. Epub 2014 Jan 19.

[6] Council of the European Union: Council Directive 2010/32/EU of 10 May 2010 implementing the framework agreement on prevention from sharp injuries in the hospital and healthcare sector concluded by HOSPEEM and EPSU (text with EEA relevance). Off J Eur Union L134/661.6.2010. ELI: http://data.europa.eu/eli/ dir/2010/32/oj [accessed 23 January 2020].

[7] Maltezou HC, Wicker S, Borg M, Heininger U, Puro V, Theodoridouf M, et al Vaccination policies for health-care workers in acute health-care facilities in Europe. Vaccine 2011;29:9557-62. https://doi.org/10.1016 j.vaccine.2011.09.076. Epub 2011 Sep 29.

[8] Maltezou HC, Poland GA. Vaccination policies for health care workers in Europe. Vaccine 2014;323:4876-80. https://doi.org/10.1016 i.vaccine.2013.10.046. Epub 2013 Oct 23.

[9] Galanakis E, D'Ancona FD, Jansen A, Lopalco PL. The issue of mandatory vaccination for healthcare workers in Europe. Expert Rev Vacccines 2014;13:277-2783. Available from: https://doi.org/10.1586/14760584.2014 869174 [accessed 23 January 2020].

[10] FitzSimons D, Hendrickx G, Lernout T, Badur S, Vorsters A, Van Damme P. Incentives and barriers regarding immunization against influenza and hepatitis of health care workers. Vaccine 2014;32:4849-54. https://doi.org/ 10.1016/i.vaccine.2014.06.072. Epub 2014 Jun 23.

[11] Maltezou HC, Katerelos P, Poufta S, Pavli A, Maragos A, Theodoridou M Attitudes toward mandatory occupational vaccinations and vaccination coverage against vaccine-preventable diseases of health care workers in primary health care centers. Am J Infect Control 2013;41:66-70. https://doi org/10.1016/j.ajic.2012.01.028. Epub 2012 Jun 17.

[12] Maltezou HC, Botelho-Nevers E, Brantsaeter A, Carlsson R-M, Heininger U, Hübschen JM, et al. Vaccination of healthcare personnel in Europe: update to current policies. Vaccine 2019;37:7576-84. https://doi.org/10.1016/ j.vaccine.2019.09.061 [accessed 23 January 2020].

[13] European Centre for Disease Prevention and Control Systematic review on hepatitis B and C prevalence in the EU/EEA. Stockholm: ECDC; 2016. Available from: https://www.ecdc.europa.eu/en/publications-data/systematic-reviewhepatitis-b-and-c-prevalence-eueea [accessed 23 January 2020].

[14] EUROSTAT. Products datasets; Real GDP per capita 2018; Latest update 17/08 2019. Available from: https://ec.europa.eu/eurostat/databrowser/view/sdg 08_10/default/table?lang=en [accessed 23 January 2020].

[15] Cashman C, Slovak A. The occupational medicine agenda: routes and standards of specialization in occupational medicine in Europe. Occup Med 2005;55:308-11.

[16] EUROSTAT. The Census Hub; population census 2011; 2014. Available from: https://ec.europa.eu/CensusHub2/query.do?step=selectHyperCube\&qhc=false [accessed 23 January 2020].

[17] World Health Organization, Geneva. WHO Global Health Workforce Statistics - December 2018 update. Available from: https://www.who.int/hrh/statistics/ hwfstats/en/ [accessed 23 January 2020].

[18] Guthmann JP, Fonteneau L, Ciotti C, Bouvet E, Pelissier G, Lévy-Bruhl D, et al. Vaccination coverage of health care personnel working in health care facilities in France: results of a national survey, 2009. Vaccine 2012;30:4648-54. https://doi.org/10.1016/i.vaccine.2012.04.098. Epub 2012 May 10.

[19] Jost M, Merz B, Colombo C, Francioli P, Ruef C, Iten A, et al. Verhütung blutübertragbarer Infektionen im Gesundheitswesen - SuvaPro 2011. 106 p. Available from: http://www.sohf.ch/Themes/Liq_Biol/2869_30_D.pdf [accessed 23 January 2020].

[20] Nasjonalt folkehelseinstitutt: Anbefalinger for bruk av hepatitt B-vaksine i Norge; 2008. 40p. Available from: https://www.fhi.no/publ/eldre/ anbefalinger-for-bruk-av-hepatitt-b/ [accessed 23 January 2020].

[21] Beškovnik L, Frelih T, Skaza AT. Hepatitis B vaccination coverage of health care workers in the Celje region (article in Slovenian with English abstract). Zdravniški Vestnik 2013:82:452-7.

[22] Ganczak M, Ostrowski M, Szych Z, Korzen M. A complete HBV vaccination coverage among Polish surgical nurses in the light of anti-HBc prevalence: a cross-sectional sero-prevalence study. Vaccine 2010;28:3972-6.

[23] Vandermeulen C, Hoppenbrouwers K, Roelants M, Theeten H, Braeckman T, Maertens K, et al. Studie van de vaccinatiegraad in Vlaanderen 2016. Agentschap Zorg \& Gezondheid, Vlaanderen, Belgium. Available from: https://www.zorg-en-gezondheid.be/vaccinatiegraadstudie [accessed 23 January 2020]

[24] De Schryver A, Claesen B, Meheus A, Hambach R, van Sprundel M, François G. Hepatitis B vaccination policies for student healthcare workers in Europe. J Hosp Infection 2014;86:147-50. https://doi.org/10.1016/j.jhin.2013.11.005. Epub 2013 Dec 1.

[25] European Consensus Group on Hepatitis B Immunity. Are booster immunisations needed for lifelong hepatitis B immunity?. Lancet 2000;355:561-5. https://doi.org/10.1016/S0140-6736(99)07239-6 [accessed 23 January 2020].

[26] CDC. CDC guidance for evaluating health-care personnel for hepatitis B virus protection and for administering postexposure management. MMWR Recommendation 2013;62( $\left.\mathrm{N}^{\circ} \mathrm{RR}-10\right): 1-19$.

[27] Poorolajal J, Mahmoodi M, Majdzadeh R, Nasseri-Moghaddam S, Haghdoost A, Fotouhi A. Long-term protection provided by hepatitis B vaccine and need for booster dosis: a meta-analysis. Vaccine 2010;28:623-31. https://doi.org/ 10.1016/j.vaccine.2009.10.068 [accessed 23 January 2020].

[28] Werner JM, Abdalla A, Gara N, Ghany MG, Rehermann B. The hepatitis B vaccine protects re-exposed health care workers, but does not provide sterilizing immunity. Gastroenterology 2013;145:1026-34. https://doi.org/ 10.1053/i.gastro.2013.07.044. Epub 2013 Jul 31.

[29] Bruce MG, Bruden D, Hurlburt D, Zanis C, Thompson G, Rea G, et al. Antibody levels and protection after hepatitis B vaccine: results of a 30-year follow-up study and response to a booster dose. J Infect Dis 2016;214:16-22. https://doi. org/10.1093/infdis/jiv748. Epub 2016 Jan 21.

[30] Cardell K, Akerlind B, Sällberg M, Frydén A. Excellent response rate to a double dose of the combined hepatitis A and B vaccine in previous nonresponders to hepatitis B vaccine. J Infect Dis 2008;198:299-304. https://doi.org/10.1086/ $\underline{589722 .}$.

[31] Koc ÖM, Savelkoul PH, van Loo IH, Peeters A, Oude Lashof AM. Safety and immunogenicity of HBAI20 hepatitis B vaccine in healthy naïve and nonresponding adults. J Viral Hepat 2018;25:1048-56. https://doi.org/ 10.1111/jvh.12909 [accessed 13 January 2020].

[32] Genovese C, Picerno IA, Trimarchi G, Cannavò G, Egitto G, Cosenza B, et al. Vaccination coverage in healthcare workers: a multicenter cross-sectional study in Italy. J Prev Med Hyg 2019;60:E12-7. https://doi.org/10.15167/24214248/jpmh2019.60.1.1097 [acessessed 23 January 2020].

[33] Civljak R, Papic N, Stamenic V, Kalenic S, Kuzman I, Car J. Influenza and hepatitis B vaccination coverage among healthcare workers in Croatian hospitals: a series of cross-sectional surveys, 2006-2011. BMC Infect Dis 2013;13:520 [acessessed 20 January 2020].

[34] Ganczak M, Topczewska K, Budnik-Szymoniuk M, Korzeń M. Seroprevalence of anti-HBc, risk factors of occupationally acquired HBV infection and HBV vaccination among hospital staff in Poland: a multicenter study. BMC Publ Health 2019;19(1):298. https://doi.org/10.1186/s12889-019-6628-1 [acessessed 23 January 2020].

[35] World Health Organization. Global health sector strategy on viral hepatitis 2016-2021 - Towards ending viral hepatitis. Geneva: WHO; 2016. Available from: http://apps.who.int/iris/bitstream/handle/10665/246177/WHOHIV-2016.06-eng.pdf;jsessionid=E22A42CCE32CEF7D5C1EE2F3CE10C6BF? sequence $=1$ [accessed 23 January 2020]

[36] Byrd KK, Lu PG, Murphy TV. Hepatitis B vaccination coverage among healthcare personnel in the United States. Public Health Rep 2013:128:498-509.

[37] European Centre for Disease Prevention and Control. Hepatitis B. In: ECDC. Annual epidemiological report for 2016. Stockholm: ECDC; 2018. Available from: https://www.ecdc.europa.eu/sites/default/files/documents/AER_for_ 2016-hepatitis-B_0.PDF [accessed 23 January 2020].

[38] UEMS Section of occupational medicine. Statement on the monitoring, prevention and the compensation of occupational and work-related diseases. UEMS 2018. Available from: https://uems-occupationalmedicine.org/wpcontent/uploads/2019/05/statement_on_the_prevention_of_occupational_ diseases_uems-om_final-1.pdf [accessed 23 January 2020]. 